\title{
Study Of Signal Quality Relationship On The Number Of Clusters And Propagation Parameters In Mobile Comumunication
}

\author{
Injilia Pebrina Sari \\ Department Of Electrical Engineering, University Of North Sumatra, Jl. Dr. Mansur No. 9 Padang Bulan, Kec. \\ Medan Baru, Kota Medan 20222
}

\begin{tabular}{r}
\hline A R T I C L E I N F O \\
\hline Article history: \\
Received Aug 08, 2020 \\
Revised Sep 16, 2020 \\
Accepted Oct 30, 2020
\end{tabular}

Keywords:

Propagation Attenuation

$\mathrm{C} / \mathrm{I}$

Cluster

Guide

\begin{abstract}
A suitable telecommunications system to support a mobile communication system is a wireless communication system, which is a radio communication system complete with transmitting antennas and radio equipment. To be able to cover such a wide coverage, the coverage area is divided into sub-areas called cells. A collection of several cells is called a cluster, and several clusters will form a mobile cellular communication network area. The number of clusters in an area is affected by changes in parameters, especially the pathloss from the propagation environment. Planning in designing a communication network is needed to be able to see how much influence the parameter changes, especially the propagation attenuation factor and the number of clusters, is to make a computer program for cell planning. From the cell planning program, it can be obtained that the value of $c / i$ is influenced by changes in the value of $\mathrm{J}$ when the value of $n$ is 3.9. The value of $c / i$ when the value of $J$ is 3 is 6.5321 . The value of $\mathrm{c} / \mathrm{i}$ when the value of $\mathrm{J}$ is 4 is 8.4062 . The value of $\mathrm{c} / \mathrm{i}$ when the value of $\mathrm{J}$ is 5 is 9.8599 . The value of $\mathrm{c} / \mathrm{i}$ when the value of $J$ is 6 is 11.0476 . The value of $c / i$ when the value of $J$ is 7 is 12.0518 . The value of $\mathrm{c} / \mathrm{i}$ when the value of $\mathrm{J}$ is 8 is 12.9217 . The value of $\mathrm{c} / \mathrm{i}$ when the value of $\mathrm{J}$ is 9 is 13.6889 . The value of $\mathrm{c} / \mathrm{i}$ is influenced by changes in the value of $n$ when the value of $J$ is 15 . The value of $c / i$ when the value of $n$ is 3 is 17.0167 . The value of $c / i$ when the value of $n$ is 3.2 is 18.6698. The value of $c / i$ when the value of $n$ is 3.4 is 20.3231 . The value of $c / i$ when the value of $n$ is 3.6 is 21.9761. The value of $c / i$ when the value of $n$ is 3.8 is 23.6293 . The value of $c / i$ when the value of $n$ is 3.9 is 24.4561 . The greater the number of cells, the greater the value of the signal ratio ratio (c/i) in the propagation. The propagation attenuation value is directly proportional to the signal ratio ratio (c/i). The greater the number of cells and the propagation attenuation, the greater the signal ratio ratio $(\mathrm{c} / \mathrm{i})$. The greater the value of the signal ratio ratio $(\mathrm{c} / \mathrm{i})$, the better the received signal quality.
\end{abstract}

This is an open access article under the CC BY-NC license.

\section{Corresponding Author:}

Injilia Pebrina Sari ,

Department Of Electrical Engineering,

University Of North Sumatra,

Jl. Dr. Mansur No. 9 Padang Bulan, Kec. Medan Baru, Kota Medan 20222.

Email : injiliasari@gmail.com 


\section{INTRODUCTION}

A suitable telecommunications system to support a mobile communication system is a wireless communication system, which is a radio communication system complete with transmitting antennas and radio equipment. To be able to cover such a wide coverage, the coverage area is divided into sub-areas called cells.

A cell is essentially a radio communications center linked to a Mobile Switching Center (MSC) that manages incoming calls. The range of signal transmission in the mobile cellular communication system can be received well depending on the signal strength of the users' cell limits. Different cell sizes are influenced by geographical conditions (nature) and the amount of traffic served. The basic principle of the cellular system architecture is contained in two features, namely frequency reuse and cell splitting.

A collection of several cells is called a cluster, and several clusters will form a mobile cellular communication network area. The number of clusters in an area is affected by changes in parameters, especially the pathloss from the propagation environment.

A network that has been formed by several clusters has a quality that is not always good. This happens because the larger the cluster size, the greater the frequency reuse distance and the greater the number of cells, the fewer available channels and the less number of users that can be served in each cell.

\section{RESEARCH METHOD}

In this final project, we will discuss the effect or relation of signal quality on the number of clusters and propagation parameters on mobile communications. The steps are carried out using a computer program, namely MATLAB GUI to obtain a cell planning program application that is used to obtain the relationship or effect of signal quality on the number of clusters and propagation parameters on mobile communications. Propagation parameters are inputted into formulas with different values, thus displaying the number of clusters to be analyzed.

The steps that will be carried out to analyze in this final project are to determine the propagation parameter $(\mathrm{n})$ and the transmitter range parameter, and then determine the propagation loss equation model, determine the received power equation model from the desired signal. After determining the signal power, the interference power equation model can be determined at a certain distance. Then determine the ratio of the carrier signal to interference ratio, so that the relationship between the carrier signal to interference ratio is obtained with the interference distance and the farthest range. Then get the relationship between the ratio of the carrier signal to interference with the number of clusters.

\section{RESULTS AND DISCUSSIONS}

\subsection{Cell Planning Analysis Program}

The cell planning analysis program uses a MATLAB computer program and the steps are as follows:

a. Start. The steps are carried out using the cell planning program, the initial GUI display in MATLAB will appear, and can be seen in Figure 1. The cell planning program is attached in the Appendix. 


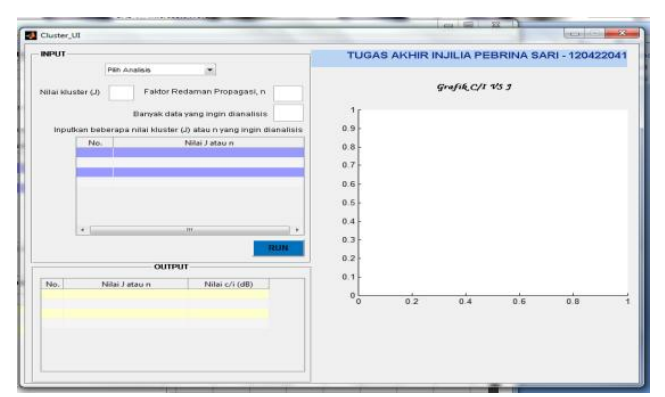

Figure 1. Initial view of the Matlab GUI of the cell planning program before it is RUN

b. Perform analysis selection:

1) Effect of $c / i$ on changes in the value of $J$

2) The effect of $c / i$ on changes in the value of $n$

3) Effect of $c / i$ on changes in the value of $J$ for some values of $n$

4) The effect of $\mathrm{c} / \mathrm{i}$ on changes in the value of $\mathrm{n}$ for some values of $\mathrm{J}$

The analysis options for the program can be seen in Figure 2 below.

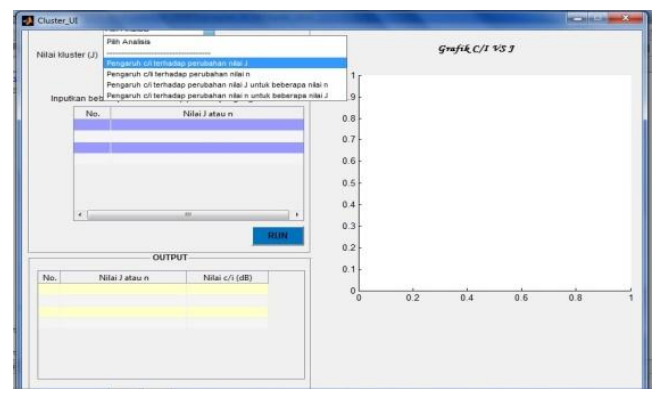

Figure 2. Display of analysis options on the program

c. If you choose a (the effect of $\mathrm{c} / \mathrm{i}$ on changes in the value of $\mathrm{J}$ ), then the following steps are carried out:

1) Enter the desired number of cells $(\mathrm{J})$

2) Entering the propagation attenuation value $(n)$

3) Click RUN, it will display a graph of the relationship between the Number of Cells $(\mathrm{J})$ with the value of $c / i$, the value of $c / i$, and a picture of the cells according to the number of input cluster values.

4) Displays an image of cells according to the number of inputs:

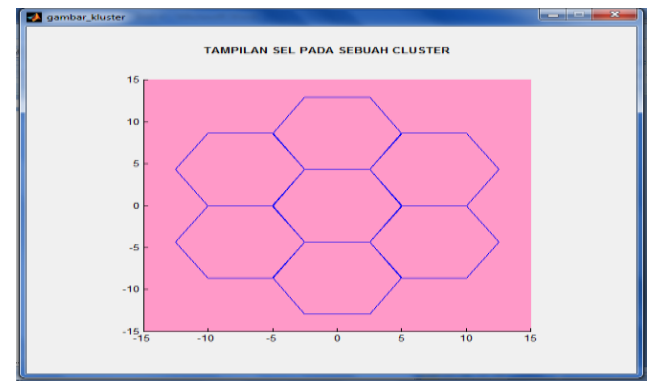

Figure 3. Display of the choice of analysis of the influence of c/i on changes in the value of $J$ 
d. If you choose b (the effect of $c / i$ on changes in the value of $n$ ), then the following steps are carried out:

1) Enter the desired number of cells $(\mathrm{J})$

2) Entering the propagation attenuation value $(n)$

3) Click RUN, then a graph of the relationship between the propagation attenuation value (n) with the $c / i$ value, $c / i$ value, and cell images will appear according to the number of input cluster values.

4) Displays an image of cells according to the number of inputs:

\subsection{Effect of $c / i$ on changes in the value of $\mathbf{J}$ on several values of $\mathbf{n}$}

$\mathrm{c} / \mathrm{i}$ in the cell planning program in the Matlab GUI is obtained from the number of cells $(\mathrm{J})$ and the propagation attenuation. The value of the propagation constant $(n)$ used is 3.9 , where the value used in mobile communication is usually a maximum of 4 , the explanation can be seen in table 4.1 [6]. The comparison of the number of cells, propagation attenuation, and $\mathrm{c} / \mathrm{i}$, with the number of cells $(J)$ differing in the form of the effect of $c / i$ on changes in the value of $J$ to several values of $n$ can be seen in Table 1.

Table 1. Propagation constants for various cluster sizes

\begin{tabular}{cc}
\hline $\mathrm{N}$ & $\mathrm{J}$ \\
\hline 2 & 101 \\
3 & 15 \\
3.5 & 9 \\
3.75 & 7 \\
4 & 6 \\
\hline
\end{tabular}

In a mobile communication system, the signal propagation between the transmitter and receiver passes through various different paths due to the features and topography of the surrounding environment into reflecting surfaces. These different paths cause the receiver signal strength to vary. In mobile communication there are two kinds of fading, namely short-term fading and long-term fading. Short term fading is mostly caused by multipath reflection of a transmitting wave from local scattering such as houses, buildings, and other structures such as trees surrounding a moving unit but not by buildings or hills located between the transmitter and receiver locations.

Table 2. Effect of $c / i$ on changes in the value of $J$ on several values of $n$

\begin{tabular}{ccc}
\hline Number of cells $(\mathrm{J})$ & Propagation Constant $(\mathrm{n})$ & $\mathrm{c} / \mathrm{i}$ \\
\hline 3 & 3.9 & 6.5321 \\
4 & 3.9 & 8.4062 \\
5 & 3.9 & 9.8599 \\
6 & 3.9 & 11.0476 \\
7 & 3.9 & 12.0518 \\
8 & 3.9 & 12.9217 \\
9 & 3.9 & 13.6889 \\
\hline
\end{tabular}

Table 2 shows the comparison between the number of cells $(\mathrm{J})$, propagation attenuation, and $\mathrm{c} / \mathrm{i}$, with different number of cells $(\mathrm{J})$., the value of the number of cells is directly proportional to the value of the signal ratio ratio $(\mathrm{c} / \mathrm{i})$. 


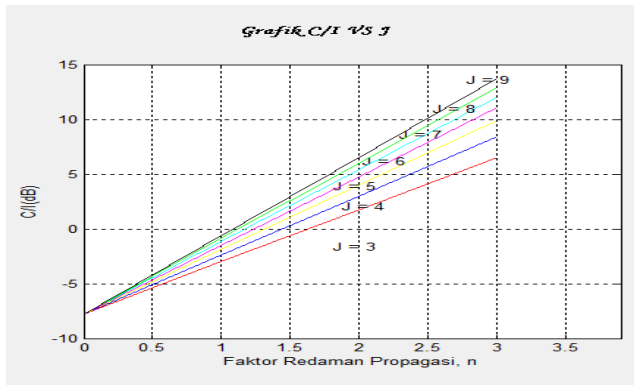

Figure 4. C/i graph for propagation attenuation with multiple cluster values

In Figure 4, you can see a graph of the ratio of the c/i signal ratio. The appearance of a cluster cell, from values $3,4,5,6,7,8$, and 9 . The graph of $\mathrm{c} / \mathrm{l}$ against the value of $\mathrm{n}$ (propagation attenuation factor) can look like a straight line on c/l starting from the point range of $6 \mathrm{~dB}$ to $15 \mathrm{~dB}$.

\subsection{Effect of $\mathbf{c} / \mathbf{i}$ on changes in the value of $\boldsymbol{n}$ on several values of $\mathbf{J}$}

Comparison between the number of cells, propagation attenuation, and $c / i$, with different values of propagation attenuation, can be done using the GUIDE program to obtain the effect of $c / i$ on changes in the value of $\mathrm{n}$ to several $\mathrm{J}$ values, as shown in Table 3.

Table 3. Effect of $c / i$ on changes in the value of $n$ on several values of $J$

\begin{tabular}{|c|c|c|}
\hline $\begin{array}{c}\text { Number of cells } \\
(\mathrm{J})\end{array}$ & Propagation constant $(\mathrm{n})$ & $\mathrm{c} / \mathrm{i}$ \\
\hline 15 & 3 & 17.0167 \\
\hline 15 & 3.2 & 18.6698 \\
\hline 15 & 3.4 & 20.3231 \\
\hline 15 & 3.6 & 21.9761 \\
\hline 15 & 3.8 & 23.6293 \\
\hline 15 & 3.9 & 24.4561 \\
\hline 15 & 4 & 25.2827 \\
\hline
\end{tabular}

Table 3 shows the comparison between the number of cells $(\mathrm{J})$, propagation attenuation, and $\mathrm{c} / \mathrm{i}$, with different propagation attenuation values. The greater the propagation attenuation value, the greater the signal ratio ratio (c/i). Thus, the attenuation value propagation is directly proportional to the ratio of the signal ratio $(\mathrm{c} / \mathrm{i})$. For different values of propagation attenuation, the $\mathrm{c} / \mathrm{i}$ graph can be seen in Figure 5.

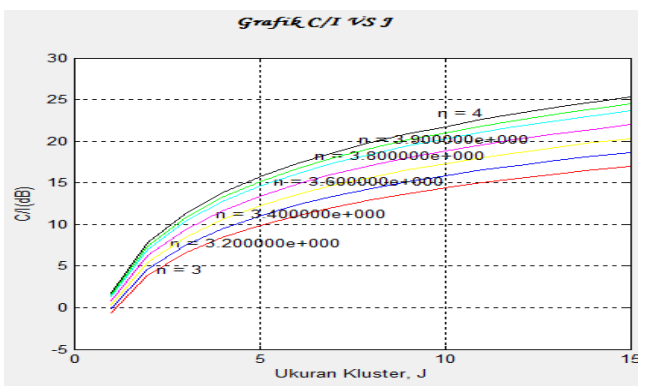

Figure 5. Graph of c/i for some values of propagation attenuation

In Figure 5, you can see a graph of the ratio of the c/i signal ratio. A cluster of 15 cells appears. The $\mathrm{c} / \mathrm{i}$ graph with $\mathrm{J}$ looks like a straight line on $\mathrm{c} / \mathrm{i}$ starting from a point range of $0.29 \mathrm{~dB}$ to $70 \mathrm{~dB}$. 
The result that has been obtained from running the cell planning program is that the greater the number of cells and the propagation attenuation, the greater the value of $c / i$ so that the better the quality of the received signal.

\section{CONCLUSION}

The value of $c / i$ is affected by changes in the value of $J$ when the value of $n$ is 3.9. The value of $c / i$ when the value of $J$ is 3 is 6.5321 . The value of $c / i$ when the value of $J$ is 4 is 8.4062 . The value of $\mathrm{c} / \mathrm{i}$ when the value of $\mathrm{J}$ is 5 is 9.8599 . The value of $\mathrm{c} / \mathrm{i}$ when the value of $\mathrm{J}$ is 6 is 11.0476 . The value of $c / i$ when the value of $J$ is 7 is 12.0518 . The value of $c / i$ when the value of $J$ is 8 is 12.9217 . The value of $c / i$ when the value of $J$ is 9 is 13.6889 .

The value of $c / i$ is affected by changes in the value of $n$ when the value of $J$ is 15 . The value of $c / i$ when the value of $n$ is 3 is 17.0167 . The value of $c / i$ when the value of $n$ is 3.2 is 18.6698 . The value of $c / i$ when the value of $n$ is 3.4 is 20.3231 . The value of $c / i$ when the value of $n$ is 3.6 is 21.9761. The value of $c / i$ when the value of $n$ is 3.8 is 23.6293 . The value of $c / i$ when the value of $n$ is 3.9 is 24.4561 . The value of $c / i$ when the value of $n$ is 4 is 25.2827 .

The greater the number of cells, the greater the value of the signal ratio ratio (c/i) in the propagation. Thus, the value of the number of cells is directly proportional to the value of the signal ratio ratio $(\mathrm{c} / \mathrm{i})$.

The greater the value of propagation attenuation, the greater the value of the signal ratio ratio (c/i). Thus, the propagation attenuation value is directly proportional to the signal ratio ratio (c/i). The larger the number of cells and the propagation attenuation, the higher the signal ratio (c/i). Thus, the number of cells and the propagation attenuation are directly proportional to the signal ratio ratio (c/i).

When the number of cells changes (j) and the value of the propagation constant (n) remains, the signal ratio ratio (c/i) increases by $9.77 \%$. When the value of the number of cells $(j)$ is fixed and the value of the propagation constant changes, the signal ratio ratio (c/i) increases by $5.44 \%$. The number of cells and the propagation constant affect the value of the signal ratio ratio, if the value of the number of cells and the propagation constant is higher, the percent increase in the signal ratio ratio will be even greater.

The greater the value of the signal ratio ratio (c/i), the better the received signal quality.

\section{REFERENCES}

John S. Seybold, 2005 “Introduction to RF Propagation", John Wiley \& Sons, Inc. Hoboken, New Jersey. Abhijit Mitra, 2000 "Lecture Notes on Mobile Communication", Indian Institue of Technology Guwahati, India. Aisyah Novfitri, Konsep Pada Seluler-Komunikasi Bergerak, (diakses pada tanggal 14 Juni 2016).

Sari, I. P. (2017). Studi Relasi Kualitas Sinyal Terhadap Jumlah Klaster dan Parameter Propagasi pada Komunikasi Bergerak.

Udhayana, A. B. (1992). Studi Perbandingan Karatekristik Propagasi Gelombang Radio Pada Beberapa Sistem STKB Cellular (Doctoral dissertation, Institut Teknologi Sepuluh Nopember).

Firmansyah Kurnia, Konsep Seluler Pada Komunikasi Bergera (diakses pada tanggal 16 Juni 2016). http://repository.usu.ac.id/bitstream/123456789/41789/4/Chapter\%20ll.pdf(di akes pada tanggal 16 Juni 2016). Jose M. Hernando and F. Perez Fontan, 1999 "Introduction to Mobile Communications Engineering", Artech House, Norwood.

https://teuinsuska2009.files.wordpress.com/2010/10/modul-guideuploder-by-teuinsuska2009-wordpresscom.pdf. 